\title{
A Cable Laid Is a Cable Played: On the Hibernation Logic behind Urban Infrastructure Mines
}

Björn Wallsten, Nils Johansson and Joakim Krook

\section{Linköping University Post Print}

\section{Tweet}

N.B.: When citing this work, cite the original article.

This is an electronic version of an article published in:

Björn Wallsten, Nils Johansson and Joakim Krook, A Cable Laid Is a Cable Played: On the Hibernation Logic behind Urban Infrastructure Mines, 2013, The Journal of urban technology, (20), 3, 85-103.

The Journal of urban technology is available online at informaworldTM:

http://dx.doi.org/10.1080/10630732.2013.809222

Copyright: Taylor \& Francis (Routledge): SSH Titles

http://www.routledge.com/

Postprint available at: Linköping University Electronic Press http://urn.kb.se/resolve?urn=urn:nbn:se:liu:diva-98054 


\title{
A Cable Laid Is a Cable Played: \\ On the Hibernation Logic behind Urban Infrastructure Mines
}

\author{
Björn Wallsten, Nils Johansson, and Joakim Krook
}

ABSTRACT Our societies are reliant on metals to such an extent that the total amounts of some of them in the built environment are comparable in size to the remaining amounts in known mountain ores. Because of concerns about mineral scarcity, the United Nations has assessed alternative sources for metal extraction and targeted urban areas in general and infrastructure systems in particular, since these are large, spatially concentrated and rich in metals. Referring to the possibility of recovering these metal stocks, infrastructure systems constitute what material flow researchers has conceptually termed "urban mines." While most urban infrastructure is in use, significant amounts of cables and pipes have been disconnected and remain in their subsurface locations; they are "hibernating."

In this article, we analyze the occurrence of such hibernation in the Swedish city of Norrköping's urban infrastructure mine where, we know from a previous study, that every fourth kilo of infrastructure is discarded. Our applied perspective is different from the logic of system expansion as a way to meet increased demand often found in the field of infrastructure studies since we are interested in how systems are disconnected and left behind. This enables us to offer a refined understanding of the concepts of infrastructure "decline" and infrastructure "cold spots." We argue that to prevent the increase of dormant infrastructures and to engage in the urban mining of already dormant infrastructures, we must develop a sensibility to the materiality of derelict infrastructure components and the underlying causes for why they form different kinds of spatial patterns.

KEYWORDS Urban Mining; Urban Infrastructure; Infrastructure "Cold Spots;" Hibernation; Norrköping

[I]n the highly developed economies of the future, it is probable that cities will become huge, rich, and diverse mines of raw materials. These mines will differ from any now to be found because they will become richer the more and the longer they are exploited [. . . ] New veins, formerly overlooked, will be continually opened. (Jacobs, I969: I IO-I I)

Forty years after Jane Jacobs formulated her ideas on "cities as mines" (Jacobs, I969), urban mining has developed into a concept seen by material flow researchers as well as environmental protection agencies as increasingly interesting from a metal-recycling perspective (Brunner and Rechberger, 2004; Kapur and Graedel, 2006; Krook et al., 200I; SEPA, 20II). This trend should be understood in relation to how human activities have altered the prerequisites for resource extraction, since the accumulation of certain metals in our societies is by now comparable in size to the remaining deposits in known mountainous ores (Lichtensteiger, 2002; Spatari et al., 2005; Muller et al., 2006). These accumulated stocks of metals in society are mainly located in urban areas (van Beers and Graedel, 2007). Since cities are technologically unique in their dense accumulation of infrastructure systems (Sims, 2010), and since such systems are large, spatially concentrated, and rich in metals, urban infrastructure has been targeted as an alternative source for metal extraction by the United Nations (UNEP, 20IO). While the components of most infrastructure systems are in use, significant amounts have been taken out of use but not collected by waste management (Hashimoto et al., 2007; 
Wallsten et al., 20I2). Added together, such pipes and cables constitute societal metal stocks that material flow researchers describe as "hibernating." Their existence is seen as an indicator of a resource-inefficient society that dissipates mineral resources in the built environment instead of giving them new functions through resource recovery, thereby obviating the need for primary resource extraction (Bergbäck and Lohm, I997; Bertram et al., 2002).

Urban mining is a metaphorical umbrella concept that includes many different resource-recovery strategies for the built environment (IWWG, 20I2), but it has been argued that the term lacks a consistent definition (Johansson et al., 2013). In this study, we use a strict definition of urban mining, in which "urban" is understood horizontally as the area inside city limits, and "mining" is understood in a vertical sense to denote the resource recovery of secondary metals from underground. The locus is the Swedish city of Norrköping and our object of inquiry is the hibernating parts of Norrköping's subsurface infrastructure. From a preceding material flow analysis, we know that there are approximately 5,000 metric tonnes of iron, copper, and aluminum in hibernating cables and pipes underneath Norrköping. This equals a fourth of the total weight of the installed systems included in the study (Wallsten et al., 2012).

That article stops at the weight and spatial diffusion of the hibernating stocks, while the underlying social processes of how these stocks occur remain unaddressed. This limitation is shared with most other urban material flow analyses, which apply a strict environmental engineering perspective (see for example Kapur and Graedel, 2006; Daigo et al., 2007) and display a general lack of social and urban theory (Monstadt, 2009). To address this perceived need, we use insights from the research field of infrastructure studies to explore how the invisibility of infrastructure and its co-constitutive relation to the urban environment lay behind the accumulation of subsurface infrastructure cast-offs.

The aim of this article is to explain the occurrence of hibernating stocks of cables and pipes in subsurface Norrköping. We explain this occurrence as being the accumulative result of a hibernation logic inherent in the city's infrastructure provision. Understanding the hibernation logic as constituent of two separate entities describing how infrastructure parts are first disconnected and then left behind we further divided the different reasons why infrastructure is disconnected and left behind according to three spatial patterns that vary in size and distribution. We were able to formulate two relevant research questions:

Why are parts, zones, and wholes of urban infrastructure systems disconnected?

Why are these disconnected parts, zones and wholes left behind in their subsurface location?

Our findings uncover how material wasting is deeply entangled in the provision of subsurface infrastructure. This is an academically neglected characteristic of subsurface infrastructure and constitutes an addition to the field of infrastructure studies. Besides academics, practitioners will also be interested in recovering these stocks of hibernating infrastructure or preventing their accumulation in the future.

\section{A Theoretical Point of Departure}

A common understanding of infrastructure systems is that they are homogenous artifacts constructed as a single body to function harmoniously until they are replaced as a whole by some new technosystemic breakthrough (Stivers, 1999, cited in Graham and Thrift, 2007). Such an understanding strengthens the myth of manageability that is often conferred upon infrastructure systems, a myth that builds upon the "invisibilization" of the systems' negative externalities (May, 20I I). 
Social scholars who seek to explore critically this myth of manageability acknowledge the sociotechnical aspects of infrastructure and its reflexive relationship with the built environment (e.g., Tarr and Dupuy, I988; Graham and Marvin, 2001; Hommels, 2005; Coutard and Guy, 2007). Infrastructure systems are in this tradition understood as embedded, or sunk into and inside social and material structures; they are co-created by human decisions and the material preconditions given by the built environment. Thus, the landscape of buildings is shaped by the landscape of infrastructure and vice versa (Gullberg and Kaijser, 2004). This co-constitutive relationship is most prominent in cities whose most apparent characteristic is perhaps their networked condition (Graham and Marvin, 200I).

A socio-technical perspective on urban infrastructure might reveal how the provision of system services and the social functioning of urban spaces correlate, but it does not imply that the socioecological dimension is thoroughly explored; that is, the ways in which urban infrastructure constitutes the most substantial interface between nature and citizens in modern societies (Monstadt and Naumann, 2005). Although there are some articles that explicitly elaborate the metabolism between nature and society (e.g., Swyngedouw, 2004; Gandy, 2004), a lack of suitable analytical categories to assess the materiality of this metabolism can be observed in the perspectives traditionally found in the literature of infrastructure studies (Monstadt and Naumann, 2005).

In bringing forward the urban infrastructure mine in Norrköping as an analytical category, this study performs a material micro-turn in relation to most other infrastructure studies. We shift the focus away from the oft-studied extend-and-supply logic of systems flows (Moss, 2008) to a correlating disconnectand-leave-behind logic of material flows. In doing so, we reach an understanding of the networked city as both a socio-technical and socio-ecological process; it is a socially entangled nexus where human-made infrastructure systems transform mineral resources into accumulative hibernating stocks of metal by means of human practice and decision-making. Such a conception offers us a valuable point of departure to address how material residue result from urban transformations (Kallipoliti, 2008).

\section{Three Different Kinds of Infrastructure "Frozen Spots"}

Although this article differs from most infrastructure studies in its focus on the halted material flows of system parts and components rather than the continued flows of system services, there are two concepts from that field that are valuable for our assessment: infrastructure decline and infrastructure cold spots. Both of these concepts deal with decreased demand of system services, which is a requirement for the disconnection of system segments of any size.

The research tradition of studying large technical systems has historically assessed infrastructure systems such as the electric grid (e.g., Hughes, I983; Lagendijk, 2008), district heating networks (e.g., Summerton, I992; Magnusson, 2013), and water and sewerage systems (e.g., Melosi, 2000; Hallström, 2002). To a large extent, these studies describe system expansion as the main strategy to meet increased demand in system services, resulting in descriptions of development phases such as invention, development, innovation, transfer, and growth (Hughes, 1987). Studies with an explicit focus on infrastructure decline are few, although some elaborate on the topic (Hughes, I983, I987; Gökalp, I992; Kaijser, I994; Ekman, 2003), which is defined as the downward spiral towards obsolescence that occurs when the belief in the system's future development is lost for some reason. Decline often happens as a consequence of increased competition from other infrastructure systems that are able to deliver the same kind of service in a cheaper or more reliable way (Kaijser, 1994). 
Infrastructure decline is one reason why wholes of systems become disconnected, but it does not say anything about why these disconnected wholes of systems are left behind in their subsurface location. Infrastructure decline is furthermore not enough to explain two other spatial configurations: the parts andzones of disconnected infrastructures.

A prerequisite for any part or zone of installed infrastructure to be disconnected and left behind is that its commercial value, i.e., its necessity in the provision of system services, must be limited. Such zones of limited commercial value have been termed "cold spots" (Guy et al., I997; Moss, 2003, 2008; Naumann and Bernt, 2009) and they might occur, for example, when an urban site loses its industrial function, causing an underutilization of system flow services (Moss, 2003). Cold spots reveal a story of infrastructure development in which the utility companies are victims of urban circumstances largely beyond their control (Moss, 2008). The same story is true for most (but not all) disconnected parts of urban infrastructure, since the action of disconnecting and leaving them behind is often (but not always), a response to such circumstances. While infrastructure cold spots are defined as zones of infrastructure with limited system flows, in this article we are interested in parts, zones, and wholes of infrastructure with non-existent system flows. Our focus is on how infrastructure systems hibernate; i.e., in how cold spots become even colder, if not frozen, spots of infrastructure.

For all of the above reasons, neither infrastructure decline nor the cold spots concept is enough to describe the different spatial patterns of disconnected and left behind, i.e., hibernating infrastructure. Thus, we suggest three different metaphors as a contribution to the literature of infrastructure studies: We suggest dormant cells of infrastructure to describe hibernation patterns formed by disconnected parts of infrastructure, infrastructure paralysis to describe the hibernation pattern formed by disconnected zones of infrastructure, and infrastructure coma to describe the hibernation pattern formed by disconnected wholes of infrastructure.

\section{Analytical Framework}

\section{Choosing Norrköping and Which Systems to Include}

Norrköping is a city located in east central Sweden with a population of 84,000 (Statistics Sweden, 20 I I). Norrköping was early to industrialize and thus has an infrastructure history that stretches back to the I850s, when it became Sweden's first major industrial city (Horgby, I989). As any other city in the northern hemisphere affected by a more than Ioo years' worth of infrastructure development, subsurface Norrköping is a complex bundle of cables, tubes, pipes, culverts, manholes, bomb shelters, etc. The historical legacy of the city's infrastructure was one of the reasons Norrköping was chosen as a case study. We knew that infrastructure decline had occurred to two infrastructure systems: the pipes of the town gas grid and the cables of the DC power grid, and that both of these grids remained in their subsurface locations. More importantly, we knew that the underlying decline processes for these very systems had been outlined by Kaijser (I986), and thus we could recycle his findings instead of complementing our study with document studies of archive material. As a consequence of previous research done by our group, another important reason for choosing Norrköping was the relatively easy access, both to interviewees and to geographic information system (GIS) data with which to construct maps. (See Figures I, 2, and 3.) Following from this and fromwhat we already had done, a spatial assessment of hibernating infrastructure in Norrköping (Wallsten et al., 20I2), our results would not have been as detailed if we had chosen any other Swedish city. Having said this, it is not possible for us to determine how Norrköping differs from other cities, but we welcome future researchers exploring this matter comparatively to increase the validity of our findings. 
Deciding on which infrastructure systems to assess, we applied a material flow perspective and chose the ones putatively involving the largest quantities of metals, since they have the highest potential of substituting primary production of metal with recycling practices. AC power, district heating, water and sewerage, and street lighting were chosen as examples of currently operating systems with some hibernating components, while town gas and DC power were chosen to represent obsolete ones. We chose to include both pipe-based systems (district heating, town gas, and water and sewerage), as well as cable-based ones (street lighting and AC and DC power), since these are conceptually different in size, weight, etc.

\section{Choosing the Interviewees}

Infrastructure studies are often influenced by large technical systems (LTS) theory (Hughes, I983), and thus focus on the system providers when describing system development. Noting the critique of LTS's inbuilt "heroism" (Law, I99I) and learning fromhousehold waste studies that the perspective of microlevel practice is key to understanding the advent or "becoming" of waste or surplus material (Bulkeley and Gregson, 2009), we chose to include not only the system providers' perspective but also the views from maintenance workers. In so doing, we performed what Bowker (1994, quoted in Star, 1999) has termed an "infrastructure inversion," by which the backstage elements of work practice is foregrounded. The already installed base of infrastructure components set the preconditions for the way that maintenance workers repair the system and replace its parts, and the inversion is suitable since the "disconnect and leave behind" logic is deeply entangled in maintenance practices. We also had academic reasons to include maintenance workers since the surfacing of the often invisible work of maintenance and repair has been highlighted as a research challenge in the social sciences (Graham and Thrift, 2007).

As in many other western countries (Graham and Marvin, 200I), infrastructure in Sweden went through a trend of privatization during the I99os, and as an example, the municipality of Norrköping sold the systems for electricity and district heating together with the obsolete town gas grid. Private actors now own these, while the other systems involved in the study are still operated by the municipality (See Appendix). All the interviewed system providers have adopted the purchasersupplier modeli to organize their provision of system services, and we have thus interviewed representatives from the purchasers (system providers) and the suppliers (maintenance contractors) for each infrastructure system in Norrköping included in the study. The system providers' organizations consist mainly of white-collar workers who purchase services of repair and construction from external blue-collar maintenance contractor firms competing for supplier contracts according to procurement processes. The two most common forms of contracts are large construction projects, which most often occur in relation to grid extensions and are procured on a case-by-case basis, and framework agreements for maintenance and repair, which are procured for three to five years at a time. Our interviewees all had experience with both of these contract forms due to their longevity in the field. Most of them were employed before the era of privatization, and could thus describe how conditions have changed over time. Our questions were not specifically pointed in this direction, however, but were asked from the viewpoint of the current situation. The interviewees are represented by numbers; for detailed information on which interviewee number corresponds to which system, see the Appendix. 


\section{Assessing the Material}

Infrastructure's invisibility has become indisputable nowadays, as most citizens take their services for granted and barely notice how fundamental these systems are to urban life until they break down (LaPorte, I994; Guy et al., I997; Star, I999; Mau, 2004). On the few occasions when maintenance excavation work occurs that could enable a visible re-connection to this systemic underworld, the normal procedure is to re-route the traffic flows of cars, bikes, and pedestrians (Johnson-McGrath, 1997), as if to hide some kind of secret. "Processes of invisibilization" are naturally also prerequisites for the urban mine's existence, since a lot of the reasons why disconnected infrastructure is left behind has to do with their subsurface location (research question two). The answer to this question is found in the section titled, "Subsurface Locations Are Necessary for Hibernation" that deals with different aspects of invisibility that are common to wholes, zones, and parts of disconnected infrastructure.

The answer to the first research question is found in the next three sections dealing with the reasons why wholes, zones, and parts are disconnected. In turn, the answers to these questions were found assessing infrastructure decline (Kaijser, 1994), the deep interrelation between the urban landscapes of buildings and networks (Gullberg and Kaijser, 2004), and the hidden practices of maintenance and repair (Graham and Thrift, 2007). Taken together, the four following sections lead to the complete picture of infrastructure coma, paralysis, and dormant cells.

\section{Infrastructure Coma}

Infrastructure coma occurs when an infrastructure system is taken out of use in its entirety. In Norrköping, this has occurred to the town gas and DC electricity systems, which both went through decline phases during the first half of the twentieth century. Norrköping was Sweden's second city to install gasworks in I85I, and the town gas was used for two purposes: indoor lighting and heating of private households and industries, and public street lighting. Town gas was used for 50 years until it was supplanted by electricity between I9I0 and 1930. Electric light was easier to switch on and off, improved indoor air quality, and offered a product seemingly less dangerous than gas (Kaijser, I986). In addition, the electric grid was less expensive to extend to outer city areas. The heating market still presented an option for further expansion of town gas operations, partly as a differentiation strategy to compete with electricity and partly due to the operational qualities of heat being consumed in daytime during most of the year in household stoves and industrial processes. Expansion could thus continue until after the Second World War, when the price of electricity was cut in half due to technological development in appliances such as electric stoves and the completion of a national Swedish transmission grid. This competition resulted in a crisis of confidence for town gas, which led to the shutdown of Swedish gasworks in the I950s and I960s (Kaijser, I986). In Norrköping, the prominent industrial sector kept town gas services up and running for a few decades more, until finally ceasing supply in 1988 causing a consecutive coma. The decrease in numbers of operating pipes had by then been ongoing for I5 years (Norrköping, I938-1985).

Another tentative explanation for the relative staying power of Norrköping's town gas deliveries is the fact that the city's electricity was installed fairly late, the 48th city in Sweden to do so. Always the competitor of town gas, DC electricity began large-scale installations in Swedish cities from the midI880s and onward. From the early I90os, the number of AC appliances grew as did the construction of AC distribution grids and over time that resulted in AC superseding DC. Many Swedish power utilities began switching from DC to AC during the I920s, a transition that in most cases was not complete 


\section{INFRASTRUCTURE COMA}

\section{CAUSED BY:}

- COMPETITION FROM NEW SYSTEMS:

- PRESSURE ON PRICES

- DECREASED DEMAND

- NO NEW MARKET EXPANSIONS AVAILABLE

- CRISIS IN CONFIDENCE

Figure I. Infrastructure "coma" occurs when infrastructure systems are suspended in their entirety after a long period of system decline. The citywide pattern shows the obsolete town gas grid and how its coherent structure is interrupted in the central parts of the city, where the pipes have been re-used to fit fiber optics. The data have been scrambled for security. 
until the I960s (Kaijser, I986). Norrköping was a case in point; the number of DC power customers decreased from 652 to two between I962 and I967 (Norrköping, I938-I985).

While neither the gas nor DC systems are used any longer, the DC power grid lies derelict underground in its entirety, but some of the town gas pipes now host fiber optics cables. Figure I shows how infrastructure coma causes a citywide hibernation pattern.

\section{Infrastructure Paralysis}

The disconnection of zones of infrastructure often occur in relation to larger city building projects (I, $2,3,4,7,8)$, such as densification $(3,5)$ and renewal $(7)$. Infrastructure paralysis is thus deeply associated with the tight interconnections between the landscape of buildings and the landscape of infrastructure. (The numbers listed here refer to system providers and maintenance contractors. They also refer to the employees of those entities who were interviewed and provided information for this study. See the Appendix.)

As in any other growing city, residential and industrial areas in Norrköping have gradually been added to the urban fringes where land prices are low and the absence of other buildings have provided windows of opportunity for exploitation. As the demand for system services increase after such housing expansions, the supporting grid must be reinforced and that results in the paralysis of suddenly under-dimensioned cables and pipes in the vicinity $(2,3,5)$. A similar dynamic occurs in relation to densification projects, since the absence of buildings and surface paving in parks and open areas often means an ideal system location due to the relatively easy access for maintenance work. When exploited, infrastructure located under such areas is often disconnected and replaced by new parts on the outskirts of the densification project $(3,5)$. Densification of buildings furthermore results in the thinning out of certain system components, such as electric transformers (5) and district heating pump stations (3), while another driver for such relocation might be efforts to lower maintenance costs $(3,4,5,7)$.

Because of how the use of buildings largely influences the need for infrastructure services, infrastructure paralysis is also caused by urban renewal (4). When an area is re-zoned from industrial to residential, the old infrastructure is replaced since newly installed components are better suited for the changed conditions and capacity needs (I, 5). Such is the case in central parts of Norrköping, which contain thousands of disconnected cables and pipes originating from the prosperous textile industry that was present up until the early parts of the twentieth century $(6,7)$. The same dynamics of paralysis would also come into play if the municipality realized its plans to develop the brownfield industrial area of

Södra Butängen in Norrköping. Given this area's close proximity to the railway station and the bundle of infrastructure that goes along with such a location, a renewal would take a large infrastructure zone out of use (7). Since system dimensioning is harder when dealing with industrial areas where customers' needs differ more than in residential housing (5), Södra Butängen is furthermore likely to contain a larger share of disconnections than other parts of the city. 


\section{INFRASTRUCTURE PARALYSIS}
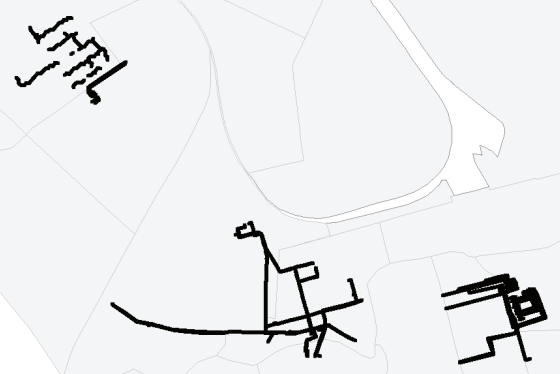

CAUSED BY:

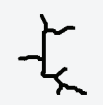

- CITY GROWTH

- DENSIFICATION

- URBAN RENEWAL

- SYSTEM UPGRADING

- RELOCATION OF OTHER SYSTEMS

Figure 2. Infrastructure "paralysis" occurs in relation to larger infrastructure projects. The flaky hibernation pattern is clustered in isolated parts of the city, where zones of infrastructure have been replaced. The data have been scrambled for security. 
While all of the above are examples of how transformations in the landscape of buildings force change and thus create surplus material in the landscape of networks, paralysis can also be caused by changes in the landscape of networks itself. Internal causes for infrastructure paralysis are often related to system upgrading. One example occurred when a large zone of sewage pipes had to be redimensioned to handle the increased run-off in the I920s, or when larger sewage pipe dimensions were needed when Norrköping got its first water treatment plant to handle the installation of flush toilets in 1972. All the old pipes that led directly into the Motala Ström river were then disconnected from the system (9). Such re-dimensioning due to increased capacity needs has also occurred in the power grid $(4,5)$ and when the old supporting DC power system for the city tram was upgraded to AC power $(5,8)$.

System expansion into areas that already have a competing system for the same kind of services might also lead to infrastructure paralysis. When extending the district heating grid into an area already using a local heating grid, the grid dimensions can be incompatible and thus the old local grid is replaced by a new one (3). Sometimes entire zones of pipes or cables are considered risks for system failures because they are too old and are thus replaced in larger sections to prevent this from happening $(3,9)$. Several of the system providers point out that changes in other systems such as altered directions of the tramline or road network force them to change their system location $(2,5,7$, 8), causing disconnections.

All of the infrastructure systems included in this study have at least to some extent, been affected by paralysis. Figure 2 shows how this causes a clustered hibernation pattern.

\section{Dormant Cells of Infrastructure}

The disconnection of parts of infrastructure most often occurs in relation to ordinary breakdowns, when the maintenance contractor replaces a dysfunctional part with a new piece instead of repairing it $(3,4,5,7,8,9)$. Thus, dormant cells of infrastructure are the results of normal failures and bad performance $(3,4,7)$ or of parts wearing out and reaching the end of their usefulness $(4,5,7,9)$. The likelihood of breakdowns is largely influenced by local environmental conditions in the shaft $(3,6,8$, 9 ), where settling $(7,8)$, elevated moisture $(3,6,7)$, and ground movement due to sudden changes in temperature $(3,6)$ are examples of factors influencing the service life of a buried cable or pipe. Other reasons for cellular dormancy involve water leaks $(3,5,9)$ and harsh traffic conditions in certain areas (6). Examples also exist of homeowners going off grid, for example disconnecting their house from the district heating grid after installing a geothermal heating system (4).

System providers sometimes accidentally cut off cables and pipes. Contractors responsible for the most deeply buried systems (water and sewage as well as district heating) are blamed for cutting off systems located above $(2,7,8)$. The contractors for these most deeply buried systems, on the other hand, find that contractors for upper systems are "very careless" when installing systems directly above theirs, since these pipes and/or cables are then in the way of their excavators (3). As a general rule, systems should differ in location vertically as well as horizontally, but since the underground is a contested space running out of suitable system locations, the ambition of separated locations is not always easy to fulfil $(3,4,5,7,9)$. Less caution is applied towards the street lighting system than the regular AC power grid, since there is no danger in cutting lighting cables off during daytime when they are not switched on (8).

While it is uncommon for contractors to damage the system they intend to repair, they direct harsh criticism at building contractors, who are said to on occasion "cut off networks on purpose to save 


\section{DORMANT CELLS OF INFRASTRUCTURE}

$\therefore \quad 1$

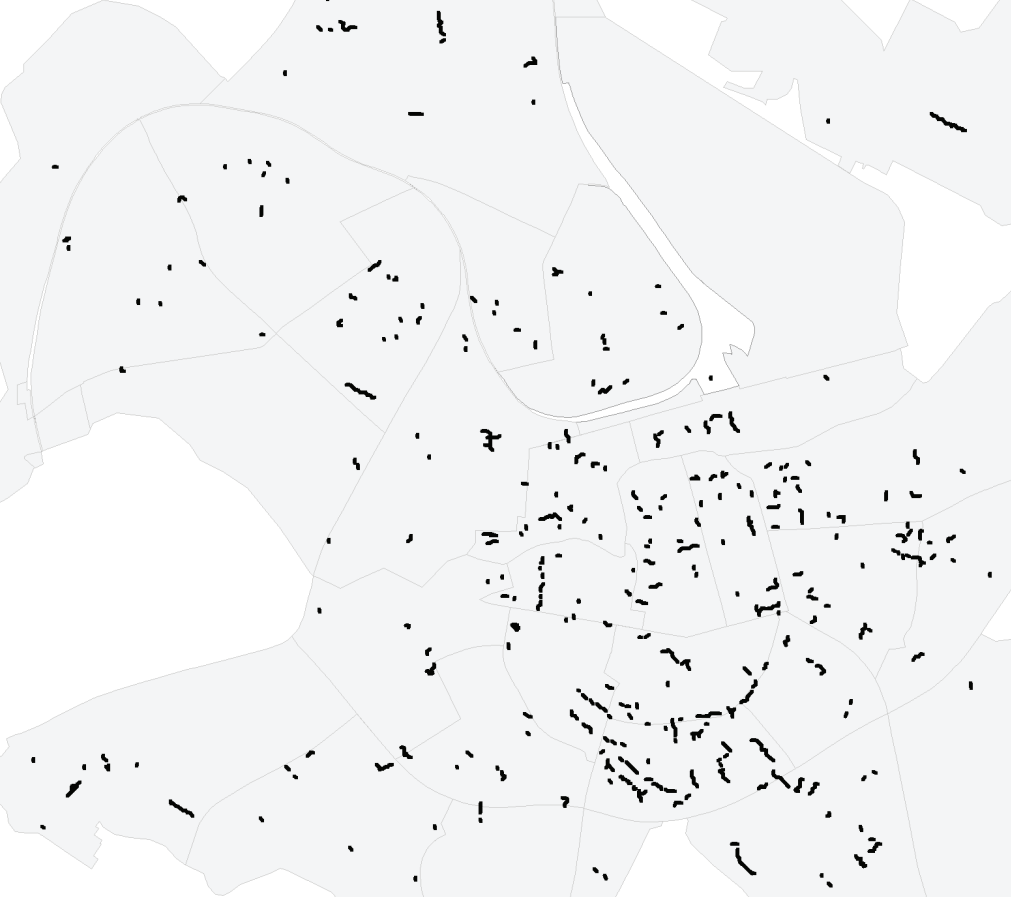

CAUSED BY:

- ORDINARY BREAKDOWNS, E.G.:

- FAILURE, BAD PERFORMANCE AND AGE

- LOCAL ENVIRONMENT CHANGES

- ACCIDENTAL AND DELIBERATE CUT-OFFS

- OFF GRID-INITIATIVES

Figure 3. "Dormant cells" of infrastructure often occur in relation to maintenance and repair. The replacement of infrastructure parts leads to a granular hibernation pattern spread out over the city. The data have been scrambled for security. 
time" (5). Both system providers ( $(1,3,5)$ and contractors $(6,8)$ agree that building contractors rarely request maps showing the location of underground systems and instead "just go without any care, oops, was this in the way!?" (I). Nor do they always report when they cut off systems, which can cause harm to the public if shafts are left open with active cables (8).

According to some of the interviewees with experience from the days when the systems were municipally owned $(5,6,8,9)$, the maintenance and repair dynamics changed significantly after the infrastructure liberalization in Sweden in the I990s. When the municipality owned the city's entire infrastructure, certain systems were co-located in shafts, which made maintenance operations easier. This was, for example, the case with the municipal electricity and street lighting cables, and the stateowned telephone wires, which to a large extent made it possible to coordinate repair work in-house. Since then, these networks have acquired three different owners (8), which results in more frequent excavation due to malfunctioning coordinating mechanisms. A steering group which is supposed to coordinate digging activities in Norrköping has been set up with monthly meetings to try to lower this frequency (I, 9), but its functioning is questioned because not all system providers are included as participants, and information gets lost during the round-up of opinions (8). The malfunctioning of this group is thought to be a consequence of severe time pressures $(3,6)$; "What is ordered tomorrow shall be fixed before yesterday" as one maintenance contractor put it (8). Time pressure is seen as a direct consequence of the new procurement arrangements in which price is paramount $(2,3,4)$.

As mentioned, infrastructure systems in Norrköping are procured in contracts stretching over three to five years in accordance with the purchaser-supplier model. Given that the contractor might not win the next maintenance round in three years and the expected lifetime of a cable is much longer than that $(2,5,8)$, the incentives to be more careful than necessary when installing new parts in the system have weakened significantly. Because of time constraints, there is, in addition, no incentive to document the system in a thorough manner $(4,8)$ and cost pressures motivate the installation of cheap, lightweight components instead of high-quality ones with longer lifespans $(5,6,8,9)$. In the long run, the risk of increased cellular dormancy and larger sections of cables and pipes malfunctioning at the same time is perceived as more likely $(5,6,8)$. The conceivable positive environmental consequences of using fewer materials for the involved components, is thus thought to be countered by decreased life expectancy of system parts in general, shifting costs onto future generations of Norrköping's citizens. Urban mining, then, to reverse the perspective, might become a more lucrative business in 20 years or so when old cables with longer life expectancy break down at the same time as more recently installed ones, which have shorter lifespans due to careless installation.

Regardless of what will happen in the future, dormant cells already exist in all of the included infrastructure systems in this study. Figure 3 shows how this causes a granular hibernation pattern.

\section{Subsurface Locations Are Necessary for Hibernation}

That the disconnected cables and pipes are also left behind is of course a requirement for all of the hibernation patterns to occur. The focus is now, therefore, shifted to why remnants of any size are left in their subsurface location.

The currently normalized notion of ubiquitous, uninterrupted infrastructure services sets the imperative for maintenance and repair work so that whenever a system section is being replaced, there are active efforts to minimize the duration of disruption in customer services. To keep the system running, the old system part is, when possible, kept in use while the new one is dug down. 
There is also the cost pressure of having open shafts to take into consideration, and larger projects are, therefore, realized in stages where shorter shaft sections are sequentially excavated and reburied. When it is time to switch to the new part in such cases, the fact that the old one remains underground makes its extraction impractical $(4,5,6,9)$.

Excavation work involves many different cost elements, such as expenditures for the actual digging, site restoration (often including re-asphalting), and the land rental from the municipality for temporary storage of excavated soil. The local authorities make sure that interrupting traffic flows for excavation work is expensive, especially in the arterial streets for buses and trams (5). Whenever a new route is chosen to replace an already existing connection, time and cost pressures result in that no one bothers to unearth the pipes and/or cables of the old route $(4,7)$. A similar dynamic is at play when the location of a route to be replaced remains intact and the convenient solution is to install the new parts above the old ones, since this makes the need to dig all the way down to the older parts unnecessary $(3,4,5,8)$. While there are many cases in which the system section that is to be replaced remains buried and thus invisible during the entire replacement process, visual access to the system is no guarantee of its extraction. For example, the sheer size of district heating and town gas pipes makes them heavy to handle (I, 4) and thus disconnected pipes are less likely to be recycled than disconnected cables.

The significant time and cost pressures associated with excavation work result in a maintenance narrative within which the only occasions when cables or pipes are recycled is when they are visible and easily accessible in their complete length during the entire replacement process; "You never dig an extra meter to extract any part of the system" (6). These conditions, then, are only present when shorter pieces of the systems are replaced $(8,9)$. Larger disconnected parts are thus more often left behind $(4,6,9)$ while the extraction of systems disconnected in their entirety is inconceivable (I).

Over time, the urban underground of Norrköping has become literally stuffed with a bundle of active and inactive parts, zones, and wholes of infrastructure systems, especially in the city center (I, 2, 3, 4, 8). This kind of system congestion can in itself be the cause of the replacement of infrastructure, if there is not enough space to relocate components in any direction $(I, 3,4,5)$.

Subsurface infrastructure furthermore has inherent problems with accuracy of documentation (Boukhelifa and Duke, 2008; Huler, 2010), which in the case of Norrköping is affected even more by the fact that hibernation is not documented in the operating GIS systems $(2,4,5,6,7,9)$. No one has digitalized the comatose DC power grid, and thus it often emerges as a surprise when digging ( 7 ). The supply of precise maps to guide the digging is also lagging, "It's like working in a headwind; it gets harder and harder to get good quality information" (4). The resulting systemic clutter makes it impossible to be totally sure whether a cable is in use or not (6): "They all look the same until you cut them off" (5). Given these conditions, extraction activities are dangerously unpredictable, risking damaging adjacent system parts $(4,6,7,8)$ and even adjacent buildings $(7)$. Repair work is also dangerous since lead (6), tarred asphalt (8), PCB plastics (5), oil (6, 8), fiber cement (4), and asbestos (3, 9) can all be found in system components.

The system providers confess a lack of procedures for handling the extraction of obsolete system parts (5), so that such activities seldom become part of the maintenance contracts: "If they [the system providers] told us to dig the cables up, then we'd have to do it" (6), and "One out of every hundred contracts mentions that the old cable should be taken care of, in those rare occasions when they [the system providers] know beforehand that its general performance is really bad" (8). The system providers furthermore express doubts about letting other actors, such as scrap metal 
recyclers, into their processes, since the latter do not have the know-how required to handle their systems (5). Yet another barrier to increasing extractions are the extra hours required to do the work and the fact that maintenance workers are in short supply in Sweden. As an example, the majority of Swedish electricians are still laying cables in the countryside after the stricter regulations that were instituted after the storm, Gudrun, hit in 2005 (5).

When handling Swedish infrastructure, you are obliged by law to seal any loose cable and pipe ends to prevent leakage of the materials mentioned above $(4,6,8)$, but that is as far as environmental policy goes in the case of infrastructure repair work; you are not required to take care of what you have put in the ground. The few wasted infrastructure cables and pipes which in fact are recycled in Norrköping today, are managed through standardized container solutions in the contractor firms' backyards $(2,6,8)$. The remaining parts destined for subsurface hibernation are not regarded as waste in a jurisdictional sense: "If so, we should have heard about it from our environmental coordinators or the media" (7). Despite the difficulty in categorizing abandoned infrastructure according to formal structures, and thus applying the existing Swedish legislation, three out of five maintenance firms (6, 8 , 9) believe that more stringent environmental regulations would force them to pick up obsolete systems parts. According to two system providers and maintenance contractors, this move should be prioritized for local environmental causes rather than resource-strategic ones (8, 9). As one contractor put it: "I prefer to leave the copper [. . .] and instead pick up the oil and lead" (6).

Disconnected systems are furthermore not easily categorized, which makes their handling difficult to regulate by means of legislation: "It can be difficult to determine when cables are totally terminated. It should not merely be decided by end of use, but rather that some time has elapsed without any use. But who should decide this?" (2). As disconnected infrastructure might be resurrected, for example when a new actor starts using an abandoned building or when fiber optics are placed in derelict gas pipes, it requires work to determine whether an element in a dig shaft is actually wasted or not. While this fuzzy condition is not adequate to describe all disconnected cables and pipes in Norrköping, it is one reason that many unused cables and pipes remain underground, without being affected by Swedish waste management regulations.

Summing up, the above outlined factors result in an urbanmine of significant volume, which is hidden from view in the nether regions of society, as is so often the case with "waste" material (Goffman, I97I, quoted in Chappells and Shove, I999). The urban mine is invisible to Norrköping's general public due to subsurface infrastructure's inherent properties and the practice of hiding maintenance work. It is invisible to system providers due to their lack of documentation (3), lack of field work experience (6), their non-existent processes for material recycling (5), and the fact that their reporting requirements to national Swedish agencies concerns cable and pipe extensions and not disconnections $(3,5)$. Finally, it is invisible to the contractors whose work practices do not always equal visual access to the systems and since the hibernating components have accumulated over long periods of time $(6,8)$. In all of these aspects, the subsurface location serves as a perfect cover-up for urban infrastructure hibernation: "What is not visible does not exist, either" (7).

\section{Conclusions}

The often-portrayed image of infrastructure systems as "characterized by perfect order, completeness, immanence, and internal homogeneity" suffers when those systems are examined closely (Graham and Thrift, 2007: 10). Here we presented a contrarian view of infrastructure by pointing at its messy and inconvenient underbelly. The normalized notion of uninterrupted system services hinders the efficient managing of the flows of components and parts. The setup of a sociotechnical system to 
optimize system flow causes a sub-optimization in terms of the system's material flows. The current privatized infrastructure paradigm supplements this material sub-optimization and will increase the subsurface systemic messiness over time, since infrastructure components are installed with less than ideal care due to the time and cost pressures caused by procurement procedures.

Although the privatization of the Swedish infrastructure sector has worsened the situation, it cannot be held solely accountable for the existence of urban infrastructure mines. In particular, urban ore bodies did exist in Norrköping before the Swedish deregulation trend in the I990s. In general, it is an unfruitful endeavor to single out any specific actor as solely responsible when dealing with this high degree of infrastructural complexity (Bennett, 2005). And so, while the system providers and their responsibility remains key to improving the situation, the occurrence of hibernating urban infrastructure as a whole must be understood as an emergence dependent on a collective of different actors. Diverse entities such as weak environmental legislation, the storm Gudrun, lead in derelict cables, imprudent excavating, and densification projects matter for how infrastructure is being provided in Norrköping today, and how the hibernation logic is an inherent characteristic to this provision. To fully understand the occurrence of frozen parts of infrastructure and the deceptively simple informal proverb: "a cable laid is a cable played" (3), all of these entities must be taken into account.

With a focus sensitive to the materiality of frozen cables and pipes, their lack of value could be reconsidered in a process characteristic of the development of waste management in general, where "waste today will not be waste tomorrow and [. . .] what was, commonsensically, waste yesterday is now incorporated as an economic 'sector'" (O'Brien, 1999: 278). As a concept based on the reincarnation of frozen infrastructure, urban mining might open up as a new line of recycling in times when the prices of metal and energy are rising and virgin resources are increasingly scarce. 


\section{Acknowledgments}

The authors would like to thank the interviewees for their participation. Valuable comments on earlier drafts of the article have been provided by Anna Küller and Dick Magnusson at the division of Technology and Social Change, while Leo Baas and Michael Martin at the division of Environmental Technology and Management and Francis Lee at the division of Technology and Social Change, are acknowledged for their help with the suggested terminology and development of applied concepts. All of the above mentioned researchers are at Linköping University, Sweden. The authors also wish to thank the anonymous peer reviewers, especially for their sound contribution to the article outline. Erik Berglund is thanked for his work with the maps and graphics. Last, the financial support from Norrköping Development Foundation and the Swedish Innovation Agency, VINNOVA, is gratefully acknowledged.

\section{Note}

I. This is a management model developed for bureaucracies that want to operate the public service as a company. The model suggests a way to achieve increased efficiency in the organization by means of contracting services from outsourced supplier firms instead of having the workforce employed in-house (Pfiffner, 2004).

\section{Note on Contributors}

Björn Wallsten is a PhD candidate at the division of Environmental Technology and Management, Linköping University, Sweden.

Nils Johansson is a PhD candidate at the division of Environmental Technology and Management, Linköping University, Sweden.

Joakim Krook is an associate professor at the division of Environmental Technology and Management, Linköping University, Sweden. 


\section{Bibliography}

- J. Bennett, “The Agency of Assemblages and the North American Blackout," Public Culture 17:3 (2005) 445-65.

- B. Bergbäck and U. Lohm, "Metals in Society," in D. Brune, D.V. Chapman, M.D. Gwynne, and J.M. Pacyna, eds., The Global Environment - Science, Technology and Management (Oslo: Scandinavian Science, 1997).

- M. Bertram, T.E. Graedel, H. Rechberger, and S. Spatari, “The Contemporary European Copper Cycle: Waste Management Subsystem," Ecological Economics 42 (2002) 43-57.

- N. Boukhelifa and D.J. Duke, "The Aesthetics of the Underworld," in P. Brown, W. Cunningham, V. Interrante, and

- J. McCormack, eds., Computational Aesthetics in Graphics, Visualization, and Imaging (Lisbon: Eurographics, 2008).

- G. Bowker, "Information Mythology and Infrastructure," in L. Bud-Friedman, ed., Information Acumen: The Understanding and Use of Knowledge in Modern Business (London: Routledge, I994).

- P. Brunner and H. Rechberger, Practical Handbook of Material Flow Analysis (Boca Raton: Lewis, 2004).

- H. Bulkeley and N. Gregson, "Crossing the Threshold: Municipal Waste Policy and Household Waste Creation," Environment and Planning A 4I (2009) 929-45.

- H. Chappells and E. Shove, “The Dustbin: A Study of DomesticWaste, Household Practices, and Utility Services,” International Planning Studies 4:2 (1999) 267-80.

- O. Coutard and S. Guy, "STS and the City: Politics and Practices of Hope," Science, Technology, \& Human Values 32:6 (2007) 713-34.

- I. Daigo, Y. Igarashi, Y. Matsuno, and Y. Adachi, “Accounting for Steel Stock in Japan,” ISIJ International 47:7 (2007) I065-9.

- T. Ekman, Spår i Vägen: Teknikual, Politik och Spåruägstrafik i Stockholm I920-2002 [Tracks along the Road - or Merely in the Way: Technology Choice, Politics and Tram Traffic in Stockholm, I920-2002] (Stockholm: Tekniska högskolan, 2003).

- M. Gandy, "Rethinking Urban Metabolism: Water, Space and the Modern City," City 8:3 (2004) 363-79.

- E. Goffman, The Representation of Self in Everyday Life (Harmondsworth: Penguin, I97I).

- S. Graham and S. Marvin, Splintering Urbanism. Networked Infrastructures, Technological Mobilities and the Urban Condition (London/New York: Routledge, 200I).

- S. Graham and N. Thrift, "Out of Order: Understanding Repair and Maintenance," Theory, Culture \& Society 24:3 (2007) I-25.

- A. Gullberg and A. Kaijser, "City-Building Regimes in Post-war Stockholm," Journal of Urban Technology I I:2 (2004) I3-39.

- S. Guy, S. Graham, and S. Marvin, "Splintering Networks: Cities and Technical Networks in I99os Britain," Urban Studies 34:2 (I997) I9I-2I6.

- I. Gökalp, "On the Analysis of Large Technical Systems," Science, Technology \& Human Values I7:I (I992) 578-87.

- J. Hallström, Constructing a Pipe-Bound City: A History of Water Supply, Sewerage, and Excreta Removal in Norrköping and Linköping, Sweden, I860-I9Iо (Linköping: Linköpings Tryckeri AB, 2002).

- S. Hashimoto, H. Tanikawa, and Y. Moriguchi, "Where Will Large Amounts of Materials Accumulated Within the Economy Go? - A Material Flow Analysis of Construction Minerals for Japan," Waste Management 27:12 (2007) I72538.

- A. Hommels, "Studying Obduracy in the City: Toward a Productive Fusion between Technology Studies and Urban Studies," Science, Technology \& Human Values 30:3 (2005) 323-5I.

- B. Horgby, Surbullestan, [Sourbun-city] (Stockholm: Carlsson Förlag, I989).

- T.P. Hughes, Networks of Power: Electrification in Western Society I880-I930 (Baltimore: Johns Hopkins University Press, I983).

- T.P. Hughes, “The Evolution of Large Technological Systems," in W. Bijker, T. Hughes, and T. Pinch, eds., The Social Construction of Technological Systems: New Directions in the Sociology and History of Technology (Cambridge, MA: MIT Press, 1987).

- S. Huler, On the Grid (New York: Rodale Books, 2010).

- IWWG - International Waste Working Group, Symposium on Urban Mining 2012 Symposium Programme (Bergamo: IWWG, 20I 2), ,http://www.urbanmining.it/SUMI 2-Symposium-Programme.pdf. Accessed March 29, 2012.

- J. Jacobs, The Economy of Cities (New York: Random House, I969).

- N. Johansson, J. Krook, M. Eklund, and B. Berglund, "Concepts for Mining the Technosphere: Towards a New Taxonomy," Journal of Cleaner Production 55 (2013) I-IO. 
- J. Johnson-McGrath, "Who Built the Built Environment? Artifacts, Politics, and Urban Technology," Technology and Culture 38:3 (1997) 690-96.

- A. Kaijser, Stadens Ljus: Etableringen av de Första Svenska Gasverken [City Lights: The Establishment of the First Swedish Gasworks] (Kristianstad: Liber Förlag, I986).

- A. Kaijser, I Fädrens Spår... .: Den Svenska Infrastrukturens Historiska Utveckling och Framtida Utmaningar [In Fathers' Tracks... .: The Historical Development and Future Challenges of Swedish Infrastructure] (Stockholm: Carlssons Bokförlag, I994).

- L. Kallipoliti, “Dross; Re-Genesis Of Diverse Matter," in D. Kelbaugh and K.K. McCulloch, eds., Writing Urbanism (New York: Routledge, 2008).

- A. Kapur and T.E. Graedel, "Copper Mines Above and Below the Ground," Environmental Science and Technology 40 (2006) 3I35-4I.

- J. Krook, A. Carlsson, M. Eklund, P. Frändegård, and N. Svensson, "Urban Mining: Hibernating Copper Stocks in Local Power Grids," Journal of Cleaner Production I9 (200I) I052-6.

- V. Lagendijk, Electrifying Europe: The Power of Europe in the Construction of Electricity Networks (Amsterdam: Aksant, 2008).

- T. LaPorte, "Large Technical Systems, Institutional Surprises and Challenges to Political Legitimacy," Technology in Society 16:3 (I994) 269-88.

- J. Law, "Introduction: Monster, Machines and Sociotechnical Relations," in J. Law, ed., A Sociology of Monsters: Essays of Power, Technology and Domination (London: Routledge, I99I).

- T. Lichtensteiger, The Petrologic Evaluation (Berlin: Springer-Verlag, 2002).

- D. Magnusson, District Heating in a Liberalized Energy Market: A New Order? Planning and Development in the Stockholm Region, I978-20I 2 (Linköping: Linköping University Press, 2013).

- B. Mau, Massive Change (London: Phaidon, 2004).

- J. May, "Infrastructuralism: The Pathology of Negative Externalities," Quaderns (September, 20I I), http://quaderns.coac.net/en/201 I/og/262-may/. Accessed March 29, 2013.

- M. Melosi, The Sanitary City: Urban Infrastructure in America from Colonial Times to the Present (Baltimore, MD: Johns Hopkins University Press, 2000).

- J. Monstadt, "Conceptualizing the Political Ecology of Urban Infrastructures: Insights from Technology and Urban Studies," Environment and Planning A 4I (2009) I924-42.

- J. Monstadt and M. Naumann, New Geographies of Infrastructure Systems: Spatial Science Perspectives and the SocioTechnical Change of Energy and Water Supply Systems in Germany (Berlin: netWORKS-papers \# IO, 2005).

- T. Moss, "Utilities, Land-Use Change, and Urban Development: Brownfield Sites as 'Cold Spots' of Infrastructure Networks in Berlin," Environment and Planning A 35 (2003) 5 I I-29.

- T. Moss, “'Cold Spots' of Urban Infrastructure: 'Shrinking' Processes in Eastern Germany and the Modern Infrastructure Ideal," International Journal of Urban and Regional Research 32:2 (2008) 436-5I.

- D. Müller, T. Wang, B. Duval, and T.E. Graedel, "Exploring the Engine of Anthropogenic Iron Cycles," PNAS IO3 (2006) I6 I I I-I6.

- M. Naumann and M. Bernt, "When the Tap Stays Dry: Water Networks in Eastern Germany," Local Environment: The International Journal of Justice and Sustainability I4:5 (2009) 46I-7 I.

- Norrköping, Statistisk årsbok Norrköping [Statistical Yearbook - Norrköping], (Norrköping: Norrköping, I938-1985).

- M. O'Brien, "Rubbish Values: Reflections on the Political Economy of Waste," Science as Culture 8:3 (I999) $269-95$.

- J.P. Pfiffner, "Traditional Public Administration versus The New Public Management: Accountability versus

Efficiency," in A. Benz, H. Siedentopf, and K.P. Sommermann, eds., Institutionenbildung in

Regierung und Verwaltung: Festschrift fur Klaus Konig (Berling: Duncker \& Humbolt, 2004).

- SEPA (Swedish Environmental Protection Agency), Från Aufallshantering till Resurshushållning -

Sueriges Aufallsplan 20I 2-20I7 [From Waste Disposal to Resource Management - Sweden's Waste Plan 20I 2-20I7] (Stockholm: SEPA, 20I I) ,http://www.naturvardsverket.se/upload/20-omnaturvardsverket/remisser/20I I/Nynationell-avfallsplan/Remissutgava-nationell-avfallsplan-ı IogI 2.pdf. Accessed March 29, 20 I3.

- B. Sims, "Disoriented City: Infrastructure, Social Order, and the Police Response to Hurricane Katrina," in S.

Graham, ed., Disrupted Cities (New York/London: Routledge, 2010).

- S. Spatari, M. Bertram, B. Gordon, K. Henderson, and T.E. Graedel, "Twentieth-Century Copper Stocks and Flows in North America: A Dynamic Analysis," Ecological Economics 54 (2005) 37-5I.

- S.L. Star, "The Ethnography of Infrastructure," American Behavioral Scientist 43:3 (I999) 377-9I.

- Statistics Sweden, www.scb.se, Accessed November 20, 2012. 
- R. Stivers, Technology as Magic: The Triumph of the Irrational (New York: Continuum, I999).

- J. Summerton, District Heating Comes To Town: The Social Shaping of an Energy System (Linköping: Affärslitteratur AB, I992).

- E. Swyngedouw, "Circulations and Metabolisms: (Hybrid) Natures and (Cyborg) Cities, " submitted to Science as Culture (2004) ,http://socgeo.ruhosting.nl/colloquium/science.pdf. Accessed March 29, 2012.

- J.A. Tarr and G. Dupuy, Technology and the Rise of the Networked City in Europe and America (Philadelphia: Temple University Press, I988).

- UNEP, Metal Stocks in Society (International Panel for Sustainable Resource Management, Working Group on the Global Metal Flows: United Nations Environment Program, 2010).

- D. van Beers and T.E. Graedel, "Spatial Characterization of Multilevel In-use Copper and Zinc Stocks in Australia," Journal of Cleaner Production I5:8-9 (2007) 849-6I.

- B. Wallsten, A. Carlsson, P. Frändegård, and J. Krook, "To Prospect an Urban Mine - Assessing the Metal Recovery Potential of Infrastructure 'Cold Spots' in Norrköping, Sweden," Journal of Cleaner Production 55 (2013) I03-I I I. 


\section{Appendix}

The numbers continously referred to in the text, correspond to interviews with responsible employees of the following system providers and maintenance contractors. All of these are currently operating in Norrköping, Sweden.

I . Tele2, provider of fiberoptics, run in the obsolete town gas grid.

2. Eddima Teknik, contractor for fiberoptics.

3 . E.On Heat, provider of district heating and cooling

4. Skanska, contractor for district heating

5 . E.On Electricity, provider of AC power

6. Vattenfall Services, contractor for AC power

7. The Technical Office at Norrköping's municipality, provider of street lighting

8 . One Nordic, contractor for street lighting

9 . The municipally owned company Norrköping Water, provider for water and sewage. (In this case we were only able to find respondents from within the organization. The project leader did have several years of previous experience from working externally in the field, thus qualifying him as interviewee.) 